\title{
MENINGKATKAN KEMAMPUAN MENGHINDARI PERILAKU TERCELA DENGAN METODE JIGSAW SISWA KELAS X IPS 3 SMA NEGERI 2 BANGKALAN TAHUN PELAJARAN 2018/2019
}

\author{
Siti Hosniyah
}

SMA Negeri 2 Bangkalan

INFO ARTIKEL

Diterima: 2-12-2020

Disetujui: 1-2-2021

Kata Kunci:

Perilaku tercela, Jigsaw

\begin{abstract}
Abstrak: Perkembangan ilmu pengetahuan dan teknologi memungkinkan semua pihak dapat memperoleh informasi dengan melimpah, cepat dan mudah dari berbagai sumber dan tempat di dunia. Dengan demikian siswa perlu memiliki kemampuan memperoleh, memilih dan mengelola informasi untuk bertahan pada keadaan yang selalu berubah, tidak pasti dan kompetitif. Kemampuan ini membutuhkan pemikiran kritis, sistematis, logis, kreatif dan kemauan bekerjasama yang efektif. Cara berpikir seperti ini dapat dikembangkan melalui belajar Pendidikan Agama Islam karena Pendidikan Agama Islam memiliki struktur dan keterkaitan yang kuat dan jelas antar konsepnya sehingga memungkinkan kita terampil berpikir rasional. Dalam kenyataannya metode tertentu dapat menunjang pendekatan siswa aktif, asalkan metode tersebut diterapkan dengan teknik yang benar. Makin jelas tujuan pembelajaran maka makin besar kemungkinan ditemukan metode penyampaian yang paling sesuai. Pendekatan yang digunakan dalam penelitian ini adalah pendekatan kuantitatif, dengan jenis penelitian tindakan. Dalam penelitian ini peneliti berkolaborasi dengan guru lain serta dengan kepala sekolah. Peneliti terlibat langsung dalam penelitian mulai dari awal sampai penelitian berakhir. Peneliti berusaha melihat, mengamati, merasakan, menghayati, merefleksi dan mengevaluasi kegiatan pembelajaran yang berlangsung. Tahap-tahap pelaksanaan penelitian tindakan terdiri dari perencanaan (planning), pelaksanaan (acting), observasi (obseving), dan refleksi (relecting). Untuk mendapatkan hasil penelitian yang akurat maka data yang telah terkumpul dianalisis secara statistik yaitu mengunakan rumus mean atau rata-rata. Mengacu pada hipotesis tindakan yang diajukan dalam penelitian tindakan kelas ini maka dapat disimpulkan bahwa ada peningkatan motivasi dan ketuntasan belajar Pendidikan Agama Islam dan Budi Pekerti pada kompetensi dasar menghindari perilaku tercela siswa kelas X IPS 3 SMA Negeri 2 Bangkalan Tahun Pelajaran 2018/2019.
\end{abstract}

\begin{abstract}
The development of science and technology enables all parties to obtain information in abundance, quickly and easily from various sources and places in the world. Thus students need to have the ability to acquire, select and manage information to survive in changing, uncertain and competitive conditions. This ability requires critical, systematic, logical, creative thinking and a willingness to work effectively. This way of thinking can be developed through studying Islamic Religious Education because Islamic Religious Education has a strong and clear structure and linkages between its concepts that enable us to be skilled in rational thinking. In fact, certain methods can support an active student approach, provided the method is applied with the correct technique. The clearer the learning objectives, the more likely it is to find the most suitable delivery method. The approach used in this research is a quantitative approach, with the type of action research. In this study, researchers collaborated with other teachers as well as with the principal. Researchers are directly involved in the research from the beginning until the end of the study. Researchers try to see, observe, feel, appreciate, reflect and evaluate learning activities that are taking place. The stages of implementing action research consist of planning, acting, observing, and reflecting. To
\end{abstract}


KARANGAN: Jurnal Kependidikan, Pembelajaran, dan Pengembangan, Vol 03, No 01, Bulan Februari, Tahun 2021, Hal 7-14

obtain accurate research results, the data that has been collected is analyzed statistically by using the mean or average formula. Referring to the action hypothesis proposed in this classroom action research, it can be concluded that there is an increase in motivation and completeness of learning Islamic Religious Education and Character on basic competencies to avoid the disgraceful behavior of class X IPS 3 SMA Negeri 2 Bangkalan in the 2018/2019 academic year.

Nama : Siti Hosniyah

Instansil : SMA Negeri 2 Bangkalan

Agama memiliki peran yang amat penting dalam kehidupan umat manusia. Agama menjadi pemandu dalam upaya untuk mewujudkan suatu kehidupan yang bermakna, damai dan bermartabat. Perkembangan ilmu pengetahuan dan teknologi memungkinkan semua pihak dapat memperoleh informasi dengan melimpah, cepat dan mudah dari berbagai sumber dan tempat di dunia. Pendidikan adalah usaha sadar dan bertujuan untuk mengembangkan kualitas manusia yang dalam pelaksanaanya berada dalam suatu proses yang berkesinambungan dalam setiap jenjang pendidikan, semuanya berkaitan dalam suatu sistem pendidikan yang integral.

Tujuan umum pendidikan agama Islam adalah membimbing anak supaya menjadi orang muslim sejati, beriman teguh, beramal sholeh dan berakhlak mulia serta berguna bagi masyarakat agama dan negara. Penelitian Tindakan Kelas (PTK) yang dalam bahasa Inggris lazim disebut Classroom Action Research (CAR) merupakan ragam atau bentuk penelitian pembelajaran yang berkonteks kelas untuk mengubah bebagai keadaan, kenyataan, dan harapan mengenai pembelajaran agar menjadi lebih baik dan bermutu dengan cara melakukan sejumlah tindakan yang dipandang tepat dan jitu. Bagi pemerhati pendidikan, tentu saja hal tersebut mendorong untuk melibatkan diri dalam Mencari, sekaligus mencari formulasi apa yang dapat dijadikan alternatif pengelolaan pendidikan. Dalam proses pendidikan, metode yang tepat guna yang mengandung nilai-nilai intrinsik dan ekstrinsik sejalan dengan materi pelajaran dan secara fungsional dapat dipakai untuk merealisasikan nilai-nilai ideal yang terkandung dalam tujuan pendidikan. Satu komponen operasional dalam ilmu pendidikan, metode harus mengandung potensi yang bersifat mengarahkan materi pelajaran kepada tujuan pendidikan yang hendak dicapai melalui proses tahap demi tahap, baik dalam kelembagaan formal, nonformal ataupun informal. Dengan demikian menurut pendidikan, suatu metode yang baik adalah memiliki waktu dan relevansi dengan tujuan pendidikan.

Konsep dari permasalahan guru terhadap proses belajar mengajar adalah motivasi rendah, pehatian tugas pokok terabaikan dan secara tidak langsung proses belajar mengajar tidak menarik dan tidak membangkitkan daya kritis siswa. Siswa yang sampai sekarang dihadapkan pada kemerosotan moral karena tidak adanya penuntun moral walaupun pendidikan moral dan ajaran agama diajarkan akan tetapi tidak menyentuh pada perilaku psikomotorik yang seharusnya dijadikan ukuran pendidikan. Salah satu metode yang dapat dipergunakan sebagai alternatif dalam peningkatan motivasi dan ketuntasan belajar siswa adalah model Tim Ahli (Jigsaw).

\section{METODE}

Objek penelitian adalah siswa kelas X IPS 3 SMA Negeri 2 Bangkalan Tahun Pelajaran 2018/2019 dengan jumlah siswa 32 orang, namun yang memenuhi syarat penelitian 30 orang siswa. Kehadiran guru dan siswa di sekolah rata-rata cukup tinggi. Latar belakang siswa mempunyai kemampuan akademik yang cukup, dan dari latar belakang ekonomi yang heterogen.

Pelaksanaan penelitian tindakan kelas berlangsung pada kegiatan pembelajaran Pendidikan Agama Islam pada semester 1 Tahun pelajaran 2018/2019. Penelitian dilaksanakan pada mata pelajaran Pendidikan Agama Islam pada kompetensi dasar menghindari perilaku tercela. Kondisi siswa SMA Negeri 2 Bangkalan sebagian besar berasal dari desa dengan mayoritas siswa berasal dari keluarga dengan keadaan ekonomi menengah. Bahkan tidak sedikit dari siswa adalah siswa yang berasal dari keluarga miskin. Dari kondisi inilah menyebabkan perhatian orang tua terhadap 
KARANGAN: Jurnal Kependidikan, Pembelajaran, dan Pengembangan, Vol 03, No 01, Bulan Februari, Tahun 2021, Hal 7-14

anak sangatlah kurang. Kurangnya perhatian orang tua ini juga menyebabkan kurangnya minat belajar pada siswa.

Pengumpulan data bersumber dari siswa yang diajar oleh guru. Data ini dikumpulkan langsung dari siswa yang bersangkutan, atau bahkan dari guru lainnya yang juga mengajar di kelas tersebut. Data dapat berupa hasil observasi, buku catatan siswa, daftar hadir, nilai ulangan, pekerjaan rumah dan tugas-tugas sekolah, keadaan kesehatan siswa, partisipasi siswa selama pelajaran berlangsung, dan interaksi sesama siswa dalam kelompok. Dari informasi ini kemudian mengelompokkan kesulitan yang dihadapi siswa, baik yang bersifat akademis, sosial, psikologis dan emosional. Kemudian mengambil keputusan apakah masalah ini akan ditangani secara individual, kelompok kecil, atau seluruh kelas (klasikal). Adapun alur dari siklus penelitian adalah sebagai berikut :

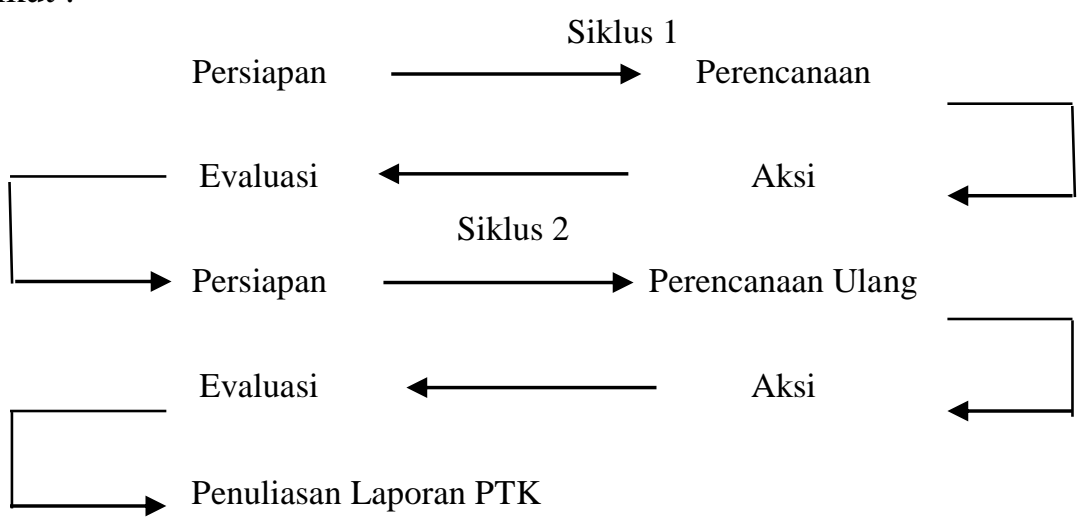

Data yang diperoleh akan dianalisis dengan statistik deskriptif secara prosentase yaitu dengan menginventarisasi dan memadukan seluruh informasi yang diperoleh dari tiap siklus. Data yang diperoleh berdasarkan :

a. Hasil observasi keaktifan siswa selama proses pembelajaran berlangsung.

b. Hasil penilaian keterampilan berbicara siswa.

Setelah data-data terkumpul, langkah selanjutnya data diolah menjadi nilai jadi. Teknik analisis data yang penulis gunakan adalah menggunakan nilai rata-rata dan prosentase ketuntasan belajar. Agar mendapat gambaran yang jelas, maka teknik statistik yang digunakan dengan rumus mean (rata-rata), yaitu: $M=\frac{\sum x}{N}$

Keterangan: $M=$ Nilai rata-rata

$\varphi x=$ Jumlah nilai siswa

$N=$ Jumlah siswa

Sedangkann untuk mengetahui prosentase ketuntasan belajar dengan rumus:

Jumlah siswa tuntas

Prosentase ketuntasan = ------------------- x 100

Jumlah seluruh kelas

Sedangkan untuk membandingkan penilaian masing-masing siklus digunakan tabel sebagai berikut:

\begin{tabular}{lccc}
\hline \multicolumn{3}{c}{ Perbandingan Nilai rata-rata dan Prosentase } \\
\hline & Siklus I & Siklus II & Peningkatan \\
\cline { 2 - 4 } Rata-rata & & \\
Prosentase & & \\
\hline
\end{tabular}

Dengan tabel tersebut diharapkan dapat diperoleh gambaran mengenai peningkatan pemahaman siswa terhadap meteri pelajaran hukum Islam tentang perilaku tercela melalui teknik Jigsaw pada siswa kelas X IPS 3 SMA Negeri 2 Bangkalan Tahun Pelajaran 2018/2019.

Kesimpulan penelitian adalah merupakan pendeskripsian pembelajaran yang terjadi pada saat penelitian. Adapun untuk mengetahui evektifitas metode yang dilakukan adalah dengan memperbandingkan hasil penelitian dari siklus pertama dengan siklus ke dua jika hasil 
KARANGAN: Jurnal Kependidikan, Pembelajaran, dan Pengembangan, Vol 03, No 01, Bulan Februari, Tahun 2021, Hal 7-14

perbadingan menunjukkan adanya peningkatan maka hipotesis penelitian dinyatakan diterima, sebaliknya jika tidak terjadi peningkatan maka hipotesis penelitian dinyatakan ditolak.

\section{HASIL}

\section{A. Gambaran Selintas Tentang Setting}

Penelitian ini menggunakan rancangan penelitian tindakan kelas (classroom based action research) dengan peningkatan pada unsur desain untuk memungkinkan diperolehnya gambaran keefektifan tindakan yang dilakukan.

Model tim ahli (Jigsaw) adalah metode pembelajaran yang dikembangkan oleh Aronson, Blaney, Stephen, Sikes dan Snapp pada tahun 1978, yang pada garis besarnya adalah metode pembelajaran yang yang menggunakan kelompok yang anggotanya sesuai dengan keadaan kelas secara heterogen (satu tim) dan tiap orang dalam tim diberi bagian materi yang berbeda.

\section{B. Hasil Penelitian}

Hasil penelitian disajikan dalam bentuk siklus yang telah dijalankan dalam periode tertentu sehingga data yang diperoleh sudah lengkap

\section{Siklus Pertama}

\section{Perencanaan}

Pada tahap proses rencana tindakan ini, mula-mula guru mengidentifikasikan pengetahuan Agama Islam pada kompetensi dasar menghindari perilaku tercela yang sukar dipahami siswa. Bardasarkan masalah tersebut, sebagai acuan implementasi tindakan yang dipilih pada konsep tersebut dipelajari dan diidentifikasi, maka guru menyusun rencana pembelajaran. Rencana pembelajaran ini memuat:
a. Pengalaman belajar dengan konsep kajian pustaka
b. Sistem pembelajaran dengan cara siswa dibagi dalam kelompok-kelompok menjadi 3 kelompok (10 anak).

c. Dalam satu kelompok tersebut diberi permasalahan yang terkait dengan pokok bahasan yang mengarah pada kemampuan dasar menghindari perilaku tercela yaitu menjelaskan pengertian ananiah, ghadhab, hasad, ghibah, dan namimah. Kelompok I membahas tentang pengertian ananiah dan bahayanya, Kelompok II tentang pengertian ghadhab dan bahayanya.dan kelompok III dalil naqli pengertian hasad dan bahayanya.

d. Kemudian masing-masing kelompok mengidentifikasikan permasalahan dengan sesama temanya untuk membahas materi yang telah dipegang sesuai dengan topik menghindari perilaku tercela yang dihadapi.

e. Semua kelompok diminta untuk mengungkapkan hasil pembahasannya dalam kelompok diskusi pleno kelas

f. Guru memberikan penekanan dan kesimpulan pada akhir diskusi terkait dengan pokok bahasan menghindari perilaku tercela.

g. Penelitian ini dilaksanakan di kelas X IPS 3 SMA Negeri 2 Bangkalan Tahun Pelajaran 2018/2019.

2. Pelaksanaan/Bentuk Tindakan

Pelaksanaan penelitian tindakan kelas (PTK) ini dilakukan pada saat kegiatan belajar mengajar di sekolah. pada jam pelajaran Pendidikan Agama Islam.

3. Teknik Observasi / Pengamatan

Teknik observasi dilakukan secara kontinue atau terus menerus dalam proses pembelajaran maupun pada hasil belajar. Evaluasi dilakukan terhadap dampak dari pemberian metode tim ahli (Jigsaw) selama proses belajar mengajar terhadap hasil belajar dan peningkatan minat siswa. Adapun nilai rata-rata hasil obeservasi siklus I adalah 76,53 dengan nilai masing-masing indikator adalah sebagai berikut:

a. Nilai rata-rata pemahaman pengertian ananiah dan bahayanya 4,17

b. Nilai rata-rata pemahaman pengertian ghadhab dan bahayanya adalah 2,85 
KARANGAN: Jurnal Kependidikan, Pembelajaran, dan Pengembangan, Vol 03, No 01, Bulan Februari, Tahun 2021, Hal 7-14

c. Nilai rata-rata pemahaman dalil naqli tentang pengertian hasad dan bahayanya adalah 2,8

d. Nilai rata-rata penyampaian materi pada siswa adalah 2,83

e. Nilai rata-rata pengambilan kesimpulan adalah 2,78

Sedangkah nilai rata-rata hasil pembelajaran siklus I adalah 70,7 degan prosentase ketuntasan 56,67\% dengan Standart Kelulusan Minimum 7,5. Adapun hasil pengamatan adalah sebagaimana terlampir.

4. Refleksi

Adapun hasil penelitian pada siklus I adalah sebagai berikut: Pada siklus pertama proses kegiatan belajar mengajar tidak seperti yang diharapkan, hal ini mungkin disebabkan dari:

a. Penyebaran anak-anak pandai tidak merata dalam setiap kelompok. Hal ini disebabkan pembagian kelompok diatur secara acak.

b. Jumlah kelompok pada siklus I mungkin terlalu banyak dimana satu kelompok terdiri dari 10 siswa. Hal ini tidak sesuai dengan teori yang diungkapkan Selvin dimana setiap kelompok terdiri dari 4 hiterogen menurut prestasi, jenis kelamin, suku dan sebagainya.

c. Kurangnya sarana dan prasarana penunjang lain seperti buku paket penunjang yang sesuai sehingga kesiapan siswa kurang baik.

d. Tidak cukup waktu bagi siswa untuk memahami modul atau diktat karena dibagikan secara mendadak.

Dengan asumasi kurang efektifan dalam proses belajar mengajar yang meliputi 4 faktor tersebut, maka hal ini diperbaiki pada siklus II.

\section{Siklus Kedua}

1. Perencanaan

Pada tahap proses rencana tindakan ini, mula-mula guru mengidentifikasikan Pengetahuan Agama Islam pada kompetensi dasar menghindari perilaku tercela dan yang sukar dipahami siswa.

Berdasarkan masalah tersebut, sebagai acuan implementasi tindakan yang dipilih pada konsep tersebut dipelajari dan didentifikasi, maka guru menyusun rencana pembelajaran. Rencana pembelajaran ini memuat:

a. Pengalaman belajar dengan konsep kajian pustaka

b. Sistem pembelajaran dengan cara siswa dibagi dalam kelompok-kelompok kecil yang terdiri dari \pm 5 orang siswa dengan salah seorang menjadi ketua

c. Dalam satu kelompok tersebut diberi permasalahan yang terkait dengan pokok bahasan yang mengarah pada kemampuan dasar menghindari perilaku tercela yaitu menyebutkan contoh-contoh perilaku ananiah, ghadhab, hasad, ghibah, dan namimah. Kelompok I \& IV menyebutkan contoh-contoh perilaku ananiah, Kelompok II \& V menyebutkan contoh-contoh perilaku ghadhab dan kelompok III \& VI dalil naqli tentang contoh-contoh perilaku namimah.

d. Kemudian masing-masing kelompok mengidentifikasikan permasalahan dengan sesama temanya untuk membahas materi yang telah dipegang sesuai dengan topik yang dihadapi.

e. Semua kelompok untuk mengungkapkan hasil bahasannya dalam kelompok diskusi pleno kelas

f. Guru memberikan penekanan dan kesimpulan pada akhir diskusi

g. Penelitian ini dilaksanakan di kelas X IPS 3 SMA Negeri 2 Bangkalan Tahun Pelajaran 2018/2019.

2. Pelaksanaan

Tindakan utama pada sklus II adalah pemberian modul/diktat untuk meningkatkan kemampuan awal (entry behavior) siswa dan merevisi kesalahan-kesalahan konsep pada siklus I, yang mungkin menyebabkan hambatan-hambatan bagi pengembangan 
KARANGAN: Jurnal Kependidikan, Pembelajaran, dan Pengembangan, Vol 03, No 01, Bulan Februari, Tahun 2021, Hal 7-14

pemahaman siswa atas konsep-konsep yang akan dipelajari. Penjajagan dilakukan dengan mengadakan test kemampuan dasar (test diagnosis).

Pelaksanaan PTK ini dilakukan pada saat kegiatan belajar mengajar di sekolah. pada jam pelajaran Pendidikan Agama Islam.

\section{Teknik Observasi/Pengamatan.}

Teknik observasi dilakukan secara kontinue atau terus menerus dalam proses pembelajaran maupun pada hasil belajar. Evaluasi dilakukan terhadap dampak dari pemberian metode tim ahli (Jigsaw) selama proses belajar mengajar terhadap hasil belajar dan peningkatan minat sisiwa.

a. Teknik observasi dilakukan secara kontinue atau terus menerus dalam proses pembelajaran maupun pada hasil belajar

b. Keaktifan anggota kelompok dalam menyelesaikan tugas.

c. Peningkatan kemampuan pada setiap kelompok.

d. Peningkatan minat siswa terhadap mata pelajaran Pendidikan Agama Islam pada kompetensi dasar menghindari perilaku tercela

Adapun nilai rata-rata hasil obeservasi siklus II adalah 82,67 dengan nilai masingmasing indikator adalah sebagai berikut:

a. Nilai rata-rata menyebutkan contoh-contoh perilaku ananiah.4,5

b. Nilai rata-rata menyebutkan contoh-contoh perilaku ghadhab adalah 4,5

c. Nilai rata-rata pemahaman Dalil naqli tentang perilaku namimah adalah 3,9

d. Nilai rata-rata penyampaian materi pada siswa adalah 3,97

e. Nilai rata-rata pengambilan kesimpulan adalah 3,83

Sedangkah nilai rata-rata hasil pembelajaran siklus II adalah 80,3 degan prosentase ketuntasan 90,00\% dengan Standart Kelulusan Minimum 7,5. Adapun hasil pengamatan adalah sebagaimana terlampir.

4. Refleksi

Pada siklus II proses kegiatan belajar mengajar sudah lebih baik dari siklus I hal ini disebabkan kelemahan-kelemahan pada siklus I sudah diperbaiki antara lain :

a. Penyebaran anak disesuaikan dengan kemampuan anak dalam kelas tersebut.

b. Kelompok siswa diperbaki dengan pengertian penyebaran heterogen satu kelas dijadikan 6 kelompok sehinga anggota msing-masing kelompok adalah 5 orang, kelompok I \& IV menyebutkan contoh-contoh perilaku ananiah, kelompok II \& V menyebutkan contoh-contoh perilaku ghadhab dan kelompok III \& VI membahas Tentang Dalil naqli tentang perilaku namimah.

c. Sarana media pembelajara dilengkapi

e. Modul atau materi pembelajaran diberikan lebih awal sehingga siswa lebih siap dalam proses belajar mengajar.

\section{Pembahasan dan Pembuktian Hipotesis}

Dari hasil observasi pada siklus I dan II dapat diketahui adanya peningkatan nilai sebagai berikut :

Tabel 1. Perbandingan Hasil Observasi Pembelajaran

\begin{tabular}{c|lcccc}
\hline No & \multicolumn{1}{|c}{ Perbandingan } & Siklus I & Silkus II & Peningkatan \\
\hline 1 & Pemahaman pengertian ananiah. & 4,17 & 4,5 & 0,33 \\
\hline 2 & Pemahaman perilaku ghadhab. & 2,85 & 4,5 & 1,65 \\
\hline 3 & $\begin{array}{l}\text { Pemahaman Dalil naqli tentang } \\
\text { perilaku naimah }\end{array}$ & 2,8 & 3,9 & 1,125 \\
\hline 4 & Penyampaian materi kepada teman & 2,83 & 3,97 & 1,145 \\
\hline 5 & Pengambilan Kesimpulan & 2,775 & 3,83 & 1,058 \\
\hline & Total Nilai & 76,53 & 82,67 & 6,137 \\
\hline
\end{tabular}

Tabel 2 Perbandingan Hasil Penilaian Pembelajaran

\begin{tabular}{ccccc}
\hline No & Perbandingan & Siklus I & Silkus II & Peningkatan \\
\hline 1 & Nilai rata-rata & 70,7 & 80,3 & 9,6 \\
\hline
\end{tabular}


KARANGAN: Jurnal Kependidikan, Pembelajaran, dan Pengembangan, Vol 03, No 01, Bulan Februari, Tahun 2021, Hal 7-14

\begin{tabular}{lllll}
\hline 2 & Prosensentase Ketuntasan & $56,67 \%$ & $90,00 \%$ & $33,33 \%$ \\
\hline
\end{tabular}

Dari pembahasan di atsa diketahi bahwa baik nilai tiap indikator, Nilai rat-rata observasi, nilai rata-rata hasil pembelajara dan prosentase pembelajaran terdapai peningkatan, maka dapat disimpulkan bahwa hipotesis yang diajukan yang berbunyi "Terdapat peningkatan kemapuan menghindari perilaku tercela dengan menggunakan metode Jigsaw pada siswa kelas X IPS 3 SMA Negeri 2 Bangkalan Tahun Pelajaran 2018/2019” dinyatakan diterima.

\section{SIMPULAN DAN SARAN}

\section{A. Kesimpulan}

Berawal dari teori tersebut diatas maka dalam mencapai mutu pembelajaran yang diinginkan, kami menggunakan metode tim ahli (Jigsaw) yang dikembangkan oleh Aronson, Blaney, Stephen, Sikes dan Snapp pada tahun 1978, yang pada garis besarnya adalah metode pembelajaran yang yang menggunakan langkah langkah sebagai berikut:

a. Membentuk kelompok yang anggotanya sesuai dengan keadaan kelas secara heterogen (satu tim)

b. Tiap orang dalam tim diberi bagian materi yang berbeda

c. Tiap orang dalam tim diberi bagian materi yang ditugaskan.

d. Anggota dari tim yang berbeda yang telah mempelajarai bagian/sub bab yang sama bertemu dalam kelompok baru (kelompok ahli) untuk mendiskusikan sub bab mereka.

e. Setelah selesai diskusi sebagi tim ahli tiap anggota kembali ke kelaompok asal dan bergantian mengajar teman satu tim mereka tentang sub bab yang mereka kuasai dan tiap anggota lainnya mendengarkan dengan sungguh-sungguh.

f. Tiap tim ahli mempresentasikan akan hasil diskusi.

g. Guru memberi evaluasi

Adapun proses perubahan yang diharapkan adalah dari aspek:

1. Guru mendominasi di kelas menjadi fasilitator

2. Siswa yang dianggap sama (prestasi sama) menjadi pelayan perbedaan perseorangan (prestasi sesuai dengan kemampuan masing-masing)

3. Pengelolaan kelas dari klasikal menjadi individual dan individual menuju klasikal, individual, kelompok dan berpasangan

4. Interaksi satu arah (dari guru ke murid berubah menjadi dua arah (guru - murid dan murid - guru)

Dengan hasil pembahasan yang dilakukan dalam penelitian tersebut maka dapat disimpulkan bahwa hipotesis penelitian yang berbunyi Terdapat peningkatan kemapuan menghindari perilaku tercela dengan menggunakan metode Jigsaw pada siswa kelas X IPS 3 SMA Negeri 2 Bangkalang Tahun Pelajaran 2018/2019 dinyatakan diterima.

\section{B. Saran-Saran}

\section{Bagi Guru}

Dalam menggunakan metode tim ahli (Jigsaw) sebaiknya:

1. Modul/diktat bahan ajar diberikan lebih awal, sehingga ada cukup waktu bagi siswa untuk memahami

2. Tugas diberikan pada siswa dalam bentuk eksperimen

3. Pada akhir pelaksanaan model tim ahli (Jigsaw) hendaknya diadakan penegasan konsep.

\section{Bagi Siswa}

Siswa diharapkan :

1. Meningkatkan rasa tanggung jawab siswa terhadap pembelajarannya.

2. Menerima keragaman dan menjalin hubungan sosialyang baik dalam hubungan belajar.

3. Meningkatkan kerja sama secara kooperatif untuk mempelajari materi yang ditugaskan. 
KARANGAN: Jurnal Kependidikan, Pembelajaran, dan Pengembangan, Vol 03, No 01, Bulan Februari, Tahun 2021, Hal 7-14

\section{DAFTAR RUJUKAN}

Buku Workshop di Batu Malang. 2005. Pedoman Pelaksanaan penelitian Tindakan kelas. Dinas Pendidikan dan Kebudayaan Propinsi Jawa Timur

Departemen Pendidikan Nasional Kurikulum 2004 SMK Pedoman Khusus Pengembangan silabus dan penilaian.

Departemen Pendidikan Nasional Kurikulum 2004. Sandar Kompetensi Mata Pelajaran Pendidikan Agama Islam.

Depdikbud. 1999. Bahan Pelatihan Penelitian Tindakan (Action Research).Jakarta: Dirjen Dikdasmen dan Dikmenum.

Nurhadi,Dr.MPd. 2004. Pembelajaran Contextual dan penerapannya dalam KBK.Universitas Negeri Malang.

Tim Pelatih Proyek PGSM. 1999. Penelitian Tindakan Kelas (Classroom Action Reseach). Departemen Pendidikan Dan Kebudayaan. Proyek Pengembangan Guru Sekolah Menengah Kejuruan.

Usman,MU. 1996. Menjadi Guru Profesionalisme. Bandung: Remaja Rosda Karya 